\title{
Glucose Amperometric Biosensor Based on the Co-immobilization of Glucose Oxidase (GOx) and Ferrocene in Poly(pyrrole) Generated from Ethanol / Water Mixtures
}

\author{
Pablo A. Fiorito and Susana I. Córdoba de Torresi * \\ Instituto de Química, Universidade de São Paulo, CP 26077, 05513-970, São Paulo - SP, Brazil
}

\begin{abstract}
Neste trabalho é apresentada a co-imobilização de GOx e ferroceno numa matriz polimérica através de um método simples de uma etapa. Esse procedimento para a imobilização de ferroceno como mediador da reação enzimática não envolve a modificação do monômero ou da enzima, o que poderia levar à perda de sua atividade. A incorporação de ferroceno se traduz no incremento da sensibilidade, comparado ao sensor sem mediador redox $\left(1,5\right.$ vs $\left.0,23 \mu \mathrm{A} \mathrm{mmol}^{-1} \mathrm{~L} \mathrm{~cm}^{-2}\right)$ e diminuição do potencial de trabalho até $0,4 \mathrm{~V}$. O sensor desenvolvido mostra resposta linear até $10 \mathrm{mmol} \mathrm{L}^{-1} \mathrm{e}$ um tempo de resposta de $2 \mathrm{~s}$, além de razoável estabilidade depois de uma semana de uso.
\end{abstract}

The co-immobilization of GOx and ferrocene in a polymeric matrix by a one-step simple method is presented. This procedure to immobilize ferrocene as mediator implies the absence of modification of the monomer or the enzyme that would lead to the loss of its activity. Ferrocene incorporation results in an increase of sensitivity compared with the sensor prepared without the redox mediator $\left(1.5 v s 0.23 \mu \mathrm{A} \mathrm{mmol}^{-1} \mathrm{~L} \mathrm{~cm}^{-2}\right)$ and the decrease of the working potential to 0.4 $\mathrm{V}$. The prepared sensor shows linear response till $10 \mathrm{mmol} \mathrm{L}^{-1}$ and response time of $2 \mathrm{~s}$, in addition to reasonable stability after one week.

Keywords: amperometric biosensor, polypyrrol, glucose detection, ferrocene mediation

\section{Introduction}

The development of amperometric biosensors is one of the major areas of interest concerning research in the detection of substances. Amperometric sensors based on oxidase enzymes that generate $\mathrm{H}_{2} \mathrm{O}_{2}$ are the most widely used biosensors, the transduction path being the electrochemical oxidation of the peroxide formed in an enzyme reaction ${ }^{1}$. In this case, the electrode response is dependent on oxygen concentration in the reaction medium.

The development of glucose amperometric biosensors is related to a primary commercial purpose and many efforts have been devoted to the fabrication of compact portable units for personal use by diabetics ${ }^{2}$. One serious problem that must be overcome for the use of a glucose biosensor in physiological samples is the presence of metabolites, such as ascorbic and uric acids, that present positive interference due to the fact that they are oxidized at the same potential as $\mathrm{H}_{2} \mathrm{O}_{2}$. Moreover, the peroxide that is generated is harmful for GOx, limiting the biosensor's performance. One viable solution for these problems is to replace the natural electron acceptor of

\footnotetext{
* e-mail: storresi@quim.iq.usp.br
}

glucose oxidase $\left(\mathrm{O}_{2}\right)$ by electroactive compounds that will act as redox mediators. These compounds will allow to work at lower potentials, avoiding in this way undesirable interferences. Redox mediators must present some characteristics that are required for the good performance of the biosensor, such as: i) fast reaction with the enzyme; ii) reversible electron transfer kinetics; iii) low overpotential regeneration; iv) electrochemical properties independent on $\mathrm{pH}$; v) stability of both oxidized and reduced forms; vi) no reaction with oxygen; vii) absence of toxicity.

Biosensors based on ferrocene derivatives ${ }^{3-5}$, quinone derivatives $^{6,7}$, organic conducting salts such as TTF-TCNQ ${ }^{8,9}$ and on osmium(II) complexes ${ }^{10}$ have been reported.

A simple method to immobilize the enzyme and the mediator on an electrode is the electrodeposition of conducting polymers, such as polypyrrole (Ppy), from solutions containing the monomer (pyrrole), the biomolecule and the mediator ${ }^{11}$. This procedure is usually carried out in aqueous solutions and is performed by applying a positive potential to a conducting substrate and following the electropolymerization current. The main advantages of this one-step method are: the control of spatial distribution of enzyme, the miniaturization of devices and the possibility of preparing multi-enzyme structures. 
As mentiored above, suitable candidates for acting as redox mediators are ferrocene and its derivatives but most of them present poor solubility in aqueous media; consequently, the functionalization of the monomer, the grafting of the enzyme or the modification of the electrode surface with ferrocene are required ${ }^{12-14}$.

In early work, Foulds and Lowe ${ }^{12}$ employed ferrocenemodified pyrrole polymers to build a glucose biosensor. Schuhmann ${ }^{13}$ used ferrocene modified glucose oxidase, both of them attached to each other via long and flexible spacer chains within conducting polymer films. Katz et $a l .{ }^{15,16}$ reported the preparation of a glucose biosensor by removing FAD (flavine adenine dinucleotide) from GOx and reintroducing the ferrocene-modified FAD again into the GOx. In this way, authors improved the electrical communication between the electrode and the reconstituted enzyme. Okawa et al. ${ }^{14}$ derivatized electrode surfaces with anchored ferrocene via long poly(oxyethylene) chains.

All the immobilization methods presented above involve very complicated chemical reactions and, in most cases, the modification of the enzyme with the mediator, which would lead to a loss of enzymatic activity.

Entrapping the mediator and the enzyme in the polymeric matrix by a one-step method is a rather simple approach. Iwakura et al. ${ }^{5}$ reported the electropolymerization of pyrrole incorporating GOx and ferrocenecarboxylate as redox mediator. However, the use of soluble or partially soluble ferrocene derivatives can provoke the leakage of the mediator from the electrode to the solution bulk. This process would lead to the decrease of the lifetime of the electrode. It is also incompatible with "in vivo" measurements.

In this paper, an alternative procedure for the coimmobilization of GOx and ferrocene in an electrochemically generated polypyrrole matrix is presented.

\section{Experimental}

\section{Materials}

Glucose oxidase (E.C. 1.1.3.4), type VII, from Aspergillium niger, 162,000 units/g solid, was purchased from Sigma. Pyrrole from Aldrich was distilled prior to use and stored under $\mathrm{N}_{2}$ atmosphere at $-4^{\circ} \mathrm{C}$. Glucose (Synth) and $\mathrm{KCl}$ (CIRQ) were of analytical grade and were used without further purification. Glucose solutions were allowed to mutarotate overnight. All solutions were prepared using ultra-pure water (Elga System UHQ).

\section{Instrumentation}

Electrochemical measurements were performed with an Autolab PGSTAT30 (Ecochemie) potentiostat/ galvanostat running under the GPES 4.7 software. All potentials are referred to a $\mathrm{Ag} / \mathrm{AgCl}$ electrode from BAS (Bioanalytical Systems), while platinum was employed as the auxiliary electrode.

Raman experiments were performed with a Renishaw Raman Imaging System 3000 coupled with an He-Ne laser (Spectra Physics, mod. 127, $\lambda_{0}=632.8 \mathrm{~nm}$ ), equipped with an Olympus metallurgical microscope and a CCD detector. Laser power was kept below $0.7 \mathrm{~mW}$ at the sample to avoid thermal degradation.

\section{Biosensor preparation}

a) Ppy/GOx biosensor: The electrode was prepared by polarizing a Pt electrode $(\phi=1.5 \mathrm{~mm}, \mathrm{BAS}, \mathrm{A}=0.0177$ $\mathrm{cm}^{2}$ ) at $0.85 \mathrm{~V}$ in an aqueous $0.05 \mathrm{~mol} \mathrm{~L}^{-1}$ pyrrol +0.1 $\mathrm{mol} \mathrm{L}-1 \mathrm{KCl}+5 \mathrm{mg} \mathrm{mL}^{-1} \mathrm{GOx}$ solution. The electropolymerization was carried out in an electrochemical microcell $(200 \mu \mathrm{L})$ using a coiled Pt wire as counter electrode and $\mathrm{Ag} / \mathrm{AgCl}$ as reference.

b) Ppy/GOx/ferrocene biosensor: The electrode was prepared by polarizing a Pt electrode $(\phi=1.5 \mathrm{~mm}$, BAS, $\left.\mathrm{A}=0.0177 \mathrm{~cm}^{2}\right)$ at $0.85 \mathrm{~V}$ in a water/ethanol $(1: 1 \mathrm{v} / \mathrm{v})$ suspension containing the ferrocene (Aldrich), the monomer, and the enzyme. Ethanolic mixtures were prepared by the following procedure: a $10 \mathrm{mg} \mathrm{mL}^{-1} \mathrm{GOx}$ $+0.1 \mathrm{~mol} \mathrm{~L}^{-1} \mathrm{KCl}+0.1 \mathrm{~mol} \mathrm{~L}^{-1}$ pyrrol aqueous solution was mixed with a $6 \times 10^{-3} \mathrm{~mol} \mathrm{~L}^{-1}$ ferrocene alcoholic solution in the proportion $1: 1 \mathrm{v} / \mathrm{v}$ to give a $5 \mathrm{mg} \mathrm{mL}^{-1} \mathrm{GOx}$ $+0.05 \mathrm{~mol} \mathrm{~L}^{-1} \mathrm{KCl}+0.05 \mathrm{~mol} \mathrm{~L}^{-1}$ pyrrol $+3 \times 10^{-3} \mathrm{~mol} \mathrm{~L}^{-1}$ ferrocene $\mathrm{H}_{2} \mathrm{O} /$ ethanol suspension. At this point, attention must be called to the fact that $\mathrm{GOx}-\mathrm{H}_{2} \mathrm{O} /$ ethanol suspensions have been reported earlier ${ }^{17}$ with no significant loss of enzyme activity.

\section{Amperometric measurements}

Tests of the biosensor's response to glucose were carried out in a conventional three-electrode electrochemical cell $(5 \mathrm{~mL})$ containing a stirred phosphate buffer solution $(0.1$ $\mathrm{mol} \mathrm{L}-1, \mathrm{pH}=7.0)$ as electrolyte. Before successive additions of glucose, the electrode was polarized at different working potentials till the stabilization of the background current.

\section{Results and Discussion}

Electropolymerization of polypyrrole (Ppy) was carried out from a $\mathrm{H}_{2} \mathrm{O}$ /ethanol suspension with the aim of incorporating ferrocene in the polymeric matrix, to play the role of redox mediator in the electron transfer between the enzyme and the electrode. Under these experimental conditions, the polymerization yield was lower than in the 
case of Ppy formed from aqueous solutions. Films of $0.017 \mathrm{C} \mathrm{cm}^{-2}$ were formed on Pt substrates, this being the optimum charge determined for glucose detection at its physiological concentration. It has been seen that thicker films reduce the performance of the electrode, probably due to mass transport of glucose inside the polymeric matrix. To achieve this charge density, 120s were needed when the ethanolic suspension was used while only 10 s were enough to form the film from aqueous solutions. This procedure led to a very thin and completely transparent film, such that the characteristic redox peaks of the Ppy/Ppy ${ }^{+}$ couple were not well defined and masked by the $\mathrm{Fc} / \mathrm{Fc}^{+}$peak.

Raman spectroscopy was used to characterize the films formed and to corroborate the presence of polypyrrole on the electrode. On the other hand, the polymerization of pyrrole from alcoholic solutions is not common and there is a lack of information about the physical characteristics of the films prepared by this method. Figure 1 shows the Raman spectra of a Ppy film formed from a $\mathrm{H}_{2} \mathrm{O}$ /ethanol suspension and the Ppy/GOx/ferrocene electrode; the spectrum of Ppy prepared from aqueous solution is also depicted for comparison. It is well known from the literature $^{18}$ that polypyrrole films prepared from aqueous solutions are less conductive than Ppy formed from acetonitrile electrolytes. Attempts have been made to relate some Raman features to this loss of conductivity; specifically, in high-conductive Ppy films ${ }^{19}$, the broad band appearing in the $1000-1050 \mathrm{~cm}^{-1}$ frequency range, assigned to the $\mathrm{C}-\mathrm{H}$ in plane deformation, presents a well defined doublet at 1045 and $1081 \mathrm{~cm}^{-1}$. It was observed that in less conducting films the intensity of the latter band diminishes or almost disappears. In addition, the intensity of the $\mathrm{C}=\mathrm{C}$ backbone stretching mode at $1586 \mathrm{~cm}^{-1}$ also diminishes. As can be seen, and in agreement with already reported data $^{20}$, the relative intensity of the band at $1081 \mathrm{~cm}^{-1}$ is lower in the Ppy spectrum (Figure 1a) and almost disappears in the Ppy prepared from the ethanolic mixture (Figure 1b). On the other hand, the band located at $1586 \mathrm{~cm}^{-1}$ becomes asymmetric, with a shoulder extending into the region below $1500 \mathrm{~cm}^{-1}$. These facts unambiguously show the lower electronic conductivity of this film when compared with Ppy prepared in aqueous solution. They could be related to the presence of alcohol in the polymerization media which would provoke nucleophilic attack on the polymeric chains, leading to the lower conductivity of the films. These features can also explain the low polymerization yield for Ppy films in $\mathrm{H}_{2} \mathrm{O}$ / ethanol solutions, demanding longer times to achieve a specific charge. Figure 1c depicts the Raman spectrum of the Ppy/GOx/ferrocene film. Attention must be paid to the absence of the characteristic bands related to ferrocene or
GOx. At this point, it must be remembered that the excitation radiation was $\lambda_{0}=632.8 \mathrm{~nm}$ and, in this case, the ferrocene is out of resonant conditions while the bands corresponding to the polymer are enhanced because of the resonant Raman effect. Nevertheless, some interesting points regarding this spectrum can be remarked. The band at $1081 \mathrm{~cm}^{-1}$ can be resolved, although with lower intensity than in the case of PPy formed in aqueous solution. The $\mathrm{C}=\mathrm{C}$ band disappears, showing only a shoulder extending below $1500 \mathrm{~cm}^{-1}$. Apparently these films are less resistive than the Ppy formed in $\mathrm{H}_{2} \mathrm{O}$ /ethanol mixtures, probably due to the presence of ferrocene.

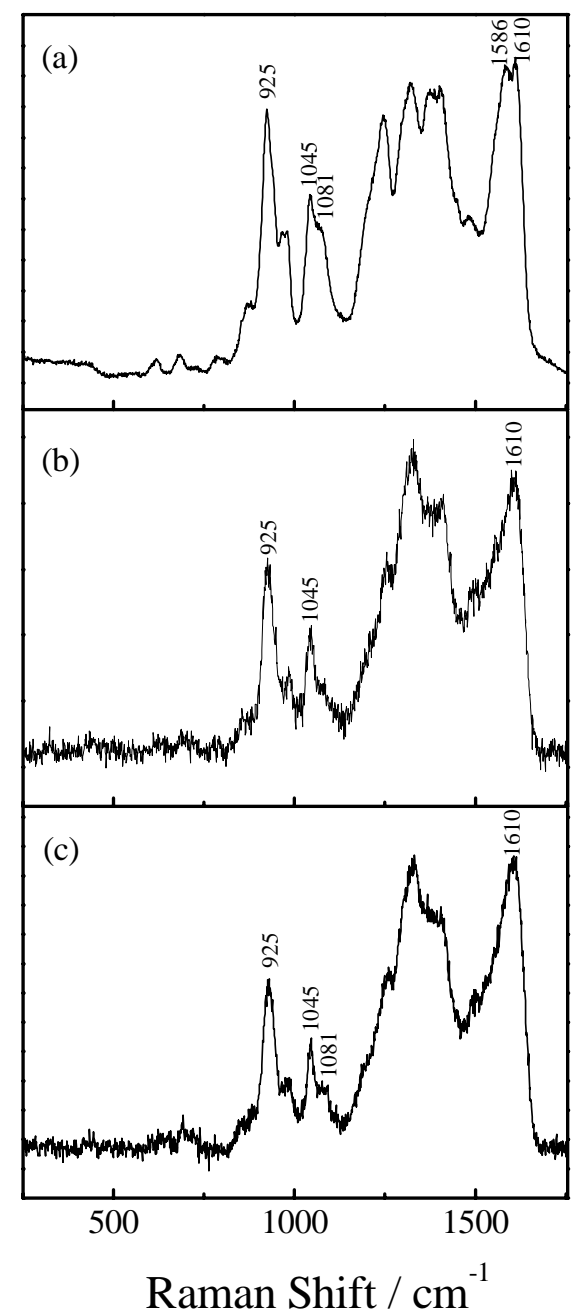

Figure 1. Raman spectra of (a) Polypyrrole film prepared from $0.1 \mathrm{~mol} \mathrm{~L}^{-1}$ $\mathrm{KCl}$ aqueous solution, (b) Polypyrrole film formed from $0.1 \mathrm{~mol} \mathrm{~L}^{-1} \mathrm{H}_{2} \mathrm{O}$ / ethanol solution, and (c) Polypyrrole/GOx/ferrocene film prepared from $0.1 \mathrm{~mol} \mathrm{~L}^{-1} \mathrm{KCl}+0.003 \mathrm{~mol} \mathrm{~L}^{-1}$ ferrocene $+10 \mathrm{mg} \mathrm{mL}^{-1} \mathrm{GOx} \mathrm{H}_{2} \mathrm{O} /$ ethanol suspension.

Figure 2 shows the current response of the Ppy/GOx (filled circles) and Ppy/GOx/Ferrocene (open circles) biosensors as a function of the applied potential for $5.6 \mathrm{mmol}$ $\mathrm{L}^{-1}$ glucose in phosphate buffer solution $\left(0.1 \mathrm{~mol} \mathrm{~L}^{-1}, \mathrm{pH}=7\right)$. 
It can be seen that for all potentials the current obtained with the biosensor containing ferrocene is $c a$. three times higher than that for the Ppy/GOx biosensor. Moreover, it must be pointed out that the response begins to increase at $0.3 \mathrm{~V}$ and reaches the maximum value at $0.4 \mathrm{~V}$ (Ppy/GOx/ Ferrocene ) or at $0.5 \mathrm{~V}$ (Ppy/GOx), showing a plateau after these values. Thus, the incorporation of the redox mediator allows the optimum working potential for glucose determination to be lowered.

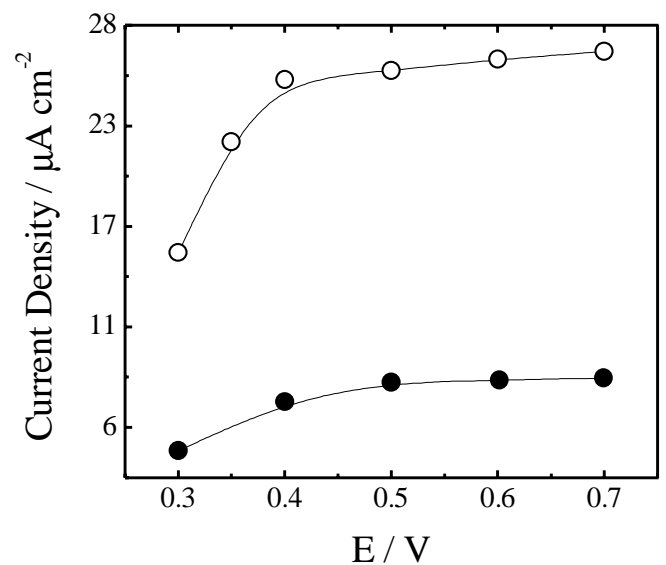

Figure 2. Effect of the applied potential on the current response of ( Ppy/GOx and (O) Ppy/GOx/ferrocene biosensors in $5.6 \mathrm{mmol} \mathrm{L}^{-1}$ glucose in buffered $(\mathrm{pH}=7.0)$ solution, saturated with air.

Figure 3 shows typical linear range calibration curves for both, $\mathrm{GO}_{\mathrm{X}}$ (filled circles) and $\mathrm{GO}_{\mathrm{X}} /$ ferrocene (open circles) biosensors, showing that they extend up to $10 \mathrm{mmol} \mathrm{L}^{-1}$ glucose. The sensitivity obtained for the electrode containing the redox mediator is $1.5 \mu \mathrm{A} \mathrm{mmol}^{-1} \mathrm{~L} \mathrm{~cm}^{-2}$ and was measured at $0.4 \mathrm{~V}$; the value shown by the Ppy/ GOx biosensor is $0.23 \mu \mathrm{A} \mathrm{mmol}{ }^{-1} \mathrm{~L} \mathrm{~cm}^{-2}$, at a working potential of $0.65 \mathrm{~V}$. This fact shows that the presence of ferrocene increases the biosensor's performance by a factor of 7, even working at a potential $250 \mathrm{mV}$ lower than in the case of the Ppy/GOx biosensor. Attention must be paid to the sensitivity obtained with the Ppy/GOx/Ferrocene electrode prepared by this method. By comparing literature data on biosensors containing ferrocene, it can be concluded that our results are very good and the preparation method very promising, mainly due to its simplicity. Katz et al ${ }^{16}$ reported a sensitivity of $c a .0 .75 \mu \mathrm{A} \mathrm{mmol}{ }^{-1} \mathrm{~L} \mathrm{~cm}^{-2}$ working at $0.35 \mathrm{~V}$ (vs. SCE) and similar values $(0.625 \mu \mathrm{A}$ $\mathrm{mmol}^{-1} \mathrm{~L} \mathrm{~cm}^{-2}$ ) were found by Foulds and Lowe ${ }^{12}$ measuring at $0.3 \mathrm{~V}$. All these biosensors perform better than the Ppy/GOx electrode but they are worse than the electrode prepared from ethanolic solutions. Very much higher sensitivities are obtained with biosensors prepared by immobilizing ferrocene containing siloxane copolymers and GOx in carbon paste electrodes ${ }^{21}$, but it must be taken into account that, in this case the amount of immobilized enzyme goes up to $5 \mathrm{mg}$.

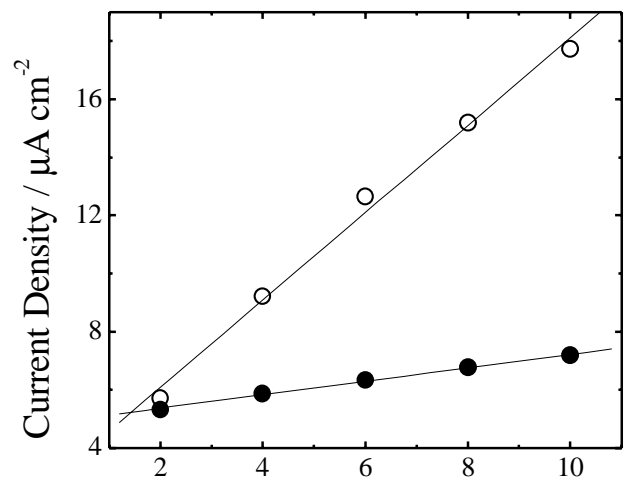

[Glicose] / $\mathrm{mmol} \mathrm{L}^{-1}$

Figure 3. Calibration plots for glucose obtained for (•) Ppy/GOx measured at $0.65 \mathrm{~V}$ and $(\mathrm{O}) \mathrm{Ppy} / \mathrm{GOx} /$ ferrocene measured at $0.4 \mathrm{~V}$ in stirred buffered $(\mathrm{pH}=7.0)$ solutions, saturated with air.

Figure 4 shows the amperometric response of the biosensor at $0.65 \mathrm{~V}$ both in air and $\mathrm{N}_{2}$-saturated buffer solutions. It can be seen that the signal obtained is higher in $\mathrm{N}_{2}$-saturated media than in air. This is another evidence of the redox mediation of ferrocene. The absence of the well known competition with oxygen in the enzyme reoxidation reaction allows for a stronger signal in the $\mathrm{N}_{2}$ saturated solution. In this figure it can also be seen that the biosensor shows a very good response time ( $c a .2 \mathrm{~s}$ ); this must be related to the immobilization of the enzyme in a very thin film generated by the present method.

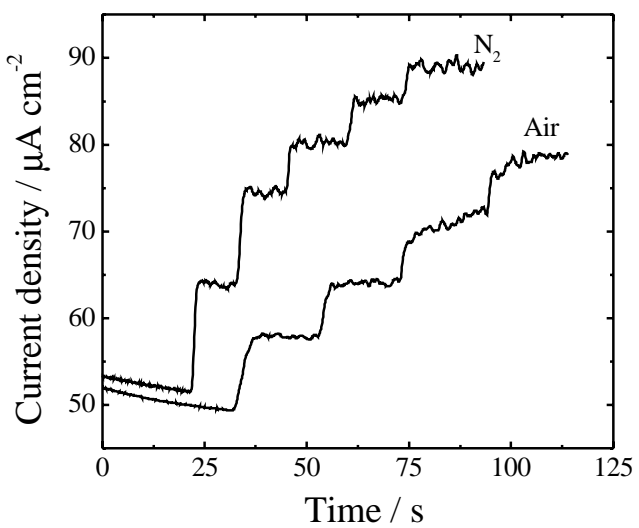

Figure 4. Amperometric response obtained at $0.65 \mathrm{~V}$ with the Ppy/GOx/ ferrocene biosensor in $\mathrm{N}_{2}$ and air saturated buffer solutions. Each current step corresponds to an increase of $2 \mathrm{mmol} \mathrm{L}^{-1}$ in glucose concentration.

Regarding the stability of the system, some tests were carried out with Ppy/GOx/ferrocene biosensors stored in phosphate buffer $(\mathrm{pH}=7)$ solutions at $4^{\circ} \mathrm{C}$. A calibration curve was performed every day during a period of 2 weeks. 
During the first 3 days, a loss of current of $c a 25 \%$ was observed; after that, the signal was stable till day 8 . From this point on, the electrical signal became very noisy and it was not possible to follow the measurements. This was attributed to the possible swelling process of the polymeric matrix that would lead to the loss of electric contact between the polymer and the substrate. This problem can be overcome by storing the electrode in dry conditions.

\section{Conclusions}

A novel and simple method, not involving enzyme or monomer modifications, for the co-immobilization of ferrocene and GOx in a poly(pyrrole) matrix for use as glucose biosensor was presented. In spite of the low conductivity of the polypyrrole film formed, the biosensor's performance is better than that of other devices reported due to redox mediation of ferrocene that lowes the working potential to $0.4 \mathrm{~V}$.

The characterization of the polymer prepared from an ethanolic suspension shows that, evidently, the presence of alcohol interferes in the polymerization kinetics. However, this plays a beneficial role because it leads to the efficient immobilization of both, the enzyme and the ferrocene, in very thin electroactive films. This fact improves the biosensor's time response, avoiding mass transport effects.

\section{Acknowledgements}

Brazilian Agencies, CNPq and FAPESP (Proc. $\mathrm{N}^{\circ}$ 98/ 7624-8) are gratefully acknowledged. P.A F. thanks FAPESP (Proc. $\mathrm{N}^{\circ}$ 99/04487-2) for the fellowship granted. Dr. M. L. A. Temperini (LEM-IQ/USP) is also acknowledged for Raman facilities.

\section{References}

1. Cattrall, R. W. In Chemical Sensors; Oxford University Press: Oxford, 1997.
2. Wilkins, E.; Atanasov, P. Med. Eng. Phys. 1996 , 18, 273.

3. Cass, A. E. G.; Davis, G.; Francis, G. D.; Hill, A. O.; Aston, W. J.; Higgins, I.; Plotkin, E. V.; Scott, L. D. L.; Turner, A. P. F. Anal. Chem. 1984, 56, 667.

4. Lange, M. A. ; Chambers, J. Q. J. Anal. Chim. Acta $\mathbf{1 9 8 5}, 175,89$.

5. Iwakura, C.; Kajiva, Y.; Yoneyama, H. J. Chem. Soc., Chem. Comm. 1988, 1019.

6. Ikeda, T.; Shibata, T.; Senda, S. J. Electroanal. Chem. 1989, 261, 351.

7. Kulys, J. J.; Cénas, N. K. Biochim. Biophys. Acta 1983, 744, 57.

8. McKenna, K.; Btajter-Toth, A. Anal. Chem. 1987, $59,954$.

9. Hale, P. D.; Skotheim, T. A. Synth. Met. 1989, 28, 853.

10. Nakabayashi, Y.; Omayu, A.; Morii, S.; Yagui, S. Sens. Actuators B 2000, 66, 128.

11. Bartlett, P. N.; Cooper, J. M. J. Electroanal. Chem. 1993, 362, 1.

12. Foulds, N. C.; Lowe, C. R. Anal. Chem. 1988, 60, 2473.

13. Schuhmann, W. Biosens. Bioelec. 1995, $10,181$.

14. Okawa, Y.; Nagano, M.; Hirota, S.; Kobayashi, H.; Ohno, T.; Watanabe, M. Biosens. Bioelec. 1999, 14, 229.

15. Riklin, A.; Katz, K.; Willner, I.; Stocker, A.; Bückmann, A. F. Nature 1995, 376, 672.

16. Katz, K.; Riklin, A.; Heleg-Shabati, V.; Willner, I.; Bückmann, A. F. Anal. Chim. Acta 1999, 385, 45.

17. Lukachova, L. V.; Karyakina ,E. E.; Karyakin, A. A.; Gorton, L. Sens. Actuators B 1997, 44, 356.

18. Liu, Y. -C.; Hwang, B. -J. Synth. Met. 2000, 113, 203.

19. Liu, Y. -C.; Hwang, B. -J. Thin Solid Films 1999, 339, 233.

20. Son, Y.; Rajeshwar, K. J. Chem. Soc. Faraday Trans. 1992, 88, 605.

21. Hale, P. D.; Boguslavsky, L. I.; Inagaki, Y.; Karan, H. I.; Lee, H. S.; Skotheim, T. A.; Okamoto, Y. Anal. Chem. 1991, 63, 677.

Received: November 29, 2000

Published on the web: August 8, 2001

FAPESP helped in meeting the publication costs of this article. 